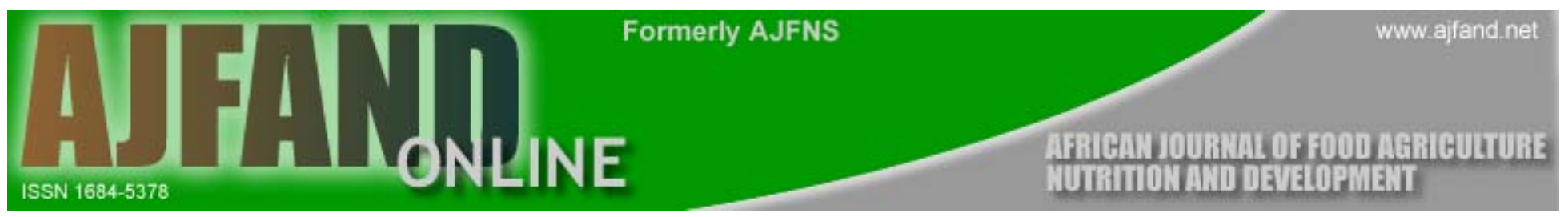

PEER REVIEWED ARTICLE No 2

\title{
CONCENTRATIONS OF TRACE METALS (LEAD, IRON, COPPER AND ZINC) IN CROPS HARVESTED IN SOME OIL PROSPECTING LOCATIONS IN RIVERS STATE, NIGERIA
}

\author{
Hart $\mathrm{AD}^{* 1}$ Oboh $\mathrm{CA}^{2}$ Barimalaa $\mathrm{IS}^{3}$ and TG Sokari ${ }^{4}$
}

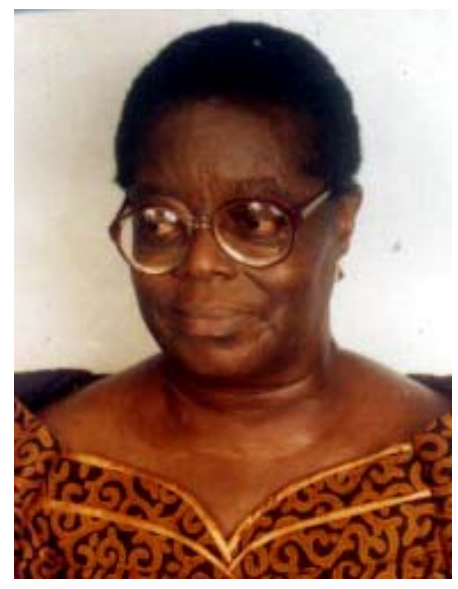

AleXander Hart

\section{* Corresponding Author}

1. Ph.D., Associate Professor, Department of Food Science and Technology, Rivers State University of Science and Technology, Nkpolu-Oroworukwo, P.M.B. 5080, Port Harcourt, Nigeria.

Tel 08037244818; Email: dradhartust@yahoo.co.uk.

2. Ph.D., Lecturer, Department of Food Science and Technology, Rivers State University of Science and Technology, Nkpolu-Oroworukwo, P.M.B. 5080, Port Harcourt, Nigeria. Presently: Nigeria Agip Oil Company, Port Harcourt, Nigeria. Tel.08033096601 Email: chris.oboh@naoc.agip.it

3. Ph.D, Associate Professor., Department of Food Science and Technology, Rivers State University of Science and Technology, Nkpolu-Oroworukwo, P.M.B. 5080, Port Harcourt, Nigeria.

Tel: 0803705904; Email: barimalaa@yahoo.com.

4. Professor of Industrial Microbiology, Department of Applied Environmental Biology, Rivers State University of Science and Technology, NkpoluOroworukwo, P.M. 5080, Port Harcourt, Nigeria. Tel: 08037076780. Email:topsoka@yahoo.com. 


\begin{abstract}
Concentrations of the trace metals lead, iron, copper and zinc were estimated in crops harvested in some oil prospecting locations in Rivers State, Nigeria. The locations were; Agbada-Aluu (AA), Ebocha (EB), Idu Ekpeye (IE), Obagi (OB) and Trans Amadi Layout (TA), with the Teaching and Research Farm of Rivers State University of Science and Technology, Port Harcourt as control. Crops investigated were cassava (Manihot esculenta), cocoyam (Colocasia esculenta), okra (Hibiscus esculentus), pumpkin leaves (Telfairia occidentalis) and waterleaf (Talinum traingulare). Results of the mean lead concentrations were from $1.1 \mu \mathrm{g} / \mathrm{g}$ in cocoyam to $9.1 \mu \mathrm{g} / \mathrm{g}$ in okro, showing higher trends in the industrialized areas. While cocoyam had the lowest lead concentration, the concentration rest of the crops did not differ significantly from one another. Crops from locations TA, OB, IE and EB had significantly higher concentrations of lead, although IE, AA and TF were not significantly different from one another. Mean concentrations of iron were between $40 \mu \mathrm{g} / \mathrm{g}$ in cassava from TF, and $651 \mu \mathrm{g} / \mathrm{g}$ in pumpkin leaves from TA - the industrial base of Rivers State reflecting a high level of pollution from the various industries in that location. Differences in concentration of iron in crops showed pumpkin leaves to have the highest level of iron, followed by the other green vegetables - waterleaf and okra although no significant differences occurred between okra, cocoyam and cassava. Copper concentrations were between $4.4 \mu \mathrm{g} / \mathrm{g}$ in cocoyam from locations TF and 23 $\mu \mathrm{g} / \mathrm{g}$ in pumpkin leaves from TA. Pumpkin leaves had the highest concentrations of copper, followed by okra, then waterleaf, with cocoyam and cassava having the least significant levels. Zinc concentrations in crops were between $29 \mu \mathrm{g} / \mathrm{g}$ in cocoyam from $\mathrm{TF}$ to $240 \mu \mathrm{g} / \mathrm{g}$ in pumpkin leaves from EB. Pumpkin leaves and okra contained the highest levels of the metal, followed by waterleaf, then cassava and finally cocoyam. In terms of location, TA, OB and EB had the highest concentrations in crops, the least occurring in TF and AA. These results reflect higher concentrations of metals in crops from the industrialized locations, with the green vegetables, particularly pumpkin leaves, having the highest uptake, while cocoyam invariably had the least. These findings give cause for concern, particularly as heavy metals are bio-accumulative in the system and portend a serious health risk to man and animals.
\end{abstract}

Key Words: Trace metals, concentrations, food crops, oil prospecting locations

\title{
FRENCH
}

Des concentrations de métaux en traces (plomb, fer, cuivre et zinc) ont été évaluées dans des cultures récoltées dans certains endroits de prospection de pétrole dans l'Etat de Rivers State, Nigeria. Ces endroits étaient Agbada-Aluu (AA), Ebocha (EB), Idu Ekpeye (IE), Obagi (OB) et Trans Amadi Layout (TA), avec la ferme d'enseignement et de recherche de l'Université des Sciences et Technologie de Rivers State, avec Port 
Harcourt comme contrôle. Les cultures qui ont fait l'objet d'analyse étaient le manioc, (Manihot esculenta), la patate douce (Colocasia esculenta), le gombo, (Hibiscus esculentus), les feuilles de courge (Telfairia occidentalis) et un légume hydrophile (Talinum traingulare). Les résultats de la moyenne des concentrations de plomb se situaient entre $1,1 \mu \mathrm{g} / \mathrm{g}$ dans la patate douce et 9,1 $\mu \mathrm{g} / \mathrm{g}$ dans le gombo, ce qui montre de plus hautes tendances dans les régions industrialisées. Alors que la patate douce avait la plus faible concentration, le reste des cultures ne différaient pas considérablement l'une de l'autre. Les cultures provenant des régions $\mathrm{TA}, \mathrm{OB}, \mathrm{IE}$ et EB avaient des concentrations nettement supérieures en plomb, tandis que celles de IE, AA et TF ne différaient pas beaucoup l'une et de l'autre. Les concentrations moyennes de fer se situaient entre $40 \mu \mathrm{g} / \mathrm{g}$ dans le manioc de TF, et $651 \mu \mathrm{g} / \mathrm{g}$ dans les feuilles de courge de TA-la base industrielle de Rivers State-ce qui reflète un niveau élevé de pollution des différentes industries de cette région. Des différences de concentration de fer dans les cultures ont montré que les feuilles de courge ont la plus haute teneur en fer, suivies par les autres légumes verts - le légume hydrophile et le gombo - bien qu'aucune grande différence ne se soit produite entre le gombo, la patate douce et le manioc. Des concentrations de cuivre se situaient entre 4,4 $\mu \mathrm{g} / \mathrm{g}$ dans la patate douce des régions $\mathrm{TF}$ et $23 \mu \mathrm{g} / \mathrm{g}$ dans les feuilles de courge des régions $\mathrm{TA}$. Les feuilles de courge avaient les plus hautes concentrations de cuivre, suivies par le gombo, puis le légume hydrophile, tandis que la patate douce et le manioc avaient les niveaux les plus bas. Les concentrations de zinc dans les cultures se situaient entre 29 $\mu \mathrm{g} / \mathrm{g}$ dans la patate douce de TF et $240 \mu \mathrm{g} / \mathrm{g}$ dans les feuilles de courge de EB. Les feuilles de courge et le gombo contenaient les niveaux les plus élevés de ce métal, puis le légume hydrophile, ensuite le manioc et finalement la patate douce. En ce qui concerne le lieu, $T A, O B$ et $E B$ avaient les concentrations les plus hautes dans les cultures, les concentrations les plus basses se trouvaient dans TF et AA. Ces résultats reflètent des concentrations de métaux plus élevées dans les cultures des régions industrialisées, tandis que les légumes verts -particulièrement les feuilles de courgeavaient la plus haute assimilation, et la patate douce avait invariablement la plus faible. Ces résultats suscitent des appréhensions, particulièrement parce que les métaux lourds sont bio-cumulatifs dans le système et qu'ils présagent de sérieux risques sanitaires pour les hommes et les animaux.

Mots-clés:

Métaux en traces, concentrations, denrées alimentaires, endroits de prospection de pétrole. 


\section{INTRODUCTION}

Increased human activities such as industrialization, coupled with over-population and increased ambient temperature amongst other factors, have become major environmental issues in recent years. Activities of oil prospecting and other industries result in pollution through gas flares, constant oil spills, and industrial effluence which affect both aquatic and terrestrial ecosystems, with destruction of forest and farmlands $[1,2]$. Rivers State, which is located in the Niger Delta region of Nigeria, is endowed with abundant oil resources, giving rise to increased industrial activities. Refining and petroleum companies account for about 70-75 percent of industrial activities in the region [3]. Petroleum refineries produce a wide variety of air and water pollutants and hazardous solid wastes. The specific mix of pollutants varies with the activities and processes involved. Frequently emitted pollutants include all the distillation products of refining. Because these facilities are usually sited in large industrial zones, often involving multiple petrochemical facilities, significant contamination of air, soil and water is usually associated with their presence. Residents of adjoining communities are potentially at risk from the inhalation of polluted air and the ingestion of polluted water. Large volumes of hazardous wastes are generated and must be appropriately disposed of, or they may adversely affect health through the contamination of soils and ground water [4]. Rapid industrialization, intensive agriculture and other anthropogenic activities have led to land degradation, environmental pollution and decline in crop productivity and sustainability. These have been of great concern to human and animal health.

One of the prominent sources contributing to increased load of soil contamination is disposal of municipal and industrial wastes. These wastes are either dumped on roadsides or used as land fills, while sewage is used for irrigation. These wastes, although useful as a source of nutrients, are also sources of carcinogens and toxic metals. Other industrial activities that take place include those from steel, glass, and paint manufacturing. Discharges from these industrial activities pollute the air, water and soil, endangering the environment as they ultimately find their way into the food chain, albeit in small doses. These accumulate overtime and across trophic levels to pose serious health hazards to man [5].

Exposure to very low levels of elements such as lead, cadmium and mercury have been shown to have cumulative effects since there is no homeostatic mechanism which can operate to regulate the levels of these toxic substances $[6,7,8]$. The major pollutants from industrial discharge have been shown to be lead, mercury, nickel, arsenic, zinc and copper. Lead intoxication has been reported to be associated with neurological problems, renal tubular dysfunction and anemia [6,9]. Although zinc and copper are essential trace elements which may also serve as plant nutrients, they may be used as components of 
paint pigments. Consequently, their undue presence in the environment through industrial discharge can also be hazardous to man $[10,11]$.

Heavy metal absorption is governed by soil characteristics such as $\mathrm{pH}$ and organic matter content $[12,13]$. Thus, high levels of heavy metals in the soil do not always indicate similar high concentrations in plants. The extent of accumulation will depend on the plant and heavy metal species under consideration. In an investigation of the uptake of $\mathrm{Cd}, \mathrm{Cu}$, $\mathrm{Ni}$ and $\mathrm{Pb}$ from air and soil by Achillea millefolium (milfoil) and Hordeum vulgare (barley) in Denmark, it was concluded that $\mathrm{Cu}$ and $\mathrm{Pb}$ plant concentrations correlated with aerial deposition but not with soil concentrations, [14]. In contrast, $\mathrm{Ni}$ and $\mathrm{Cd}$ content in the plants correlated with deposition and soil content.

In Nigeria, a study of metal concentration near Warri refinery found three to seven times elevated levels of various heavy metals in the soil [15]. Although the petroleum industry is by far the largest industrial sub sector in the Niger Delta, at least six of the eight most polluting industrial sub sectors in Nigeria (steel works, metal fabrication, food processing, textiles, refineries and paint manufacturing) operate in the Niger Delta. The Industrial Directory for Rivers State lists over 500 companies, but most of these employ fewer than ten people. Only 112 companies employ more than 50 workers [16]. The medium and large scale industries are concentrated on the Trans-Amadi Industrial Layout. The petroleum industry, including the refinery, generates most of the estimated 5,500 tons of hazardous wastes produced per year in Rivers State [17].

The increasing industrialization, particularly due to oil exploration and exploitation in Rivers State, Nigeria has created consciousness of the pollution of the environment and possible dangers emanating from such activities. Whilst literature is replete with data on heavy metal concentration in water, aquatic life and the mangrove swamp, few data exist in the Niger Delta region on heavy metal concentration in food crops. This study was therefore designed to investigate the concentration of the heavy metal lead and the essential trace elements iron, copper and zinc in food crops harvested around some oil prospecting and other industrial areas of Rivers State in Nigeria.

\section{MATERIALS AND METHODS}

\section{Study Location}

The study locations were Agbada (Aluu) (AA), Ebocha (EB), Idu Ekpeye (IE), Obagi (OB), Trans-Amadi Industrial Layout (TA) and Rivers State University of Science and Technology Teaching/Research Farm (TF). The University teaching farm, which is not located in the vicinity of any industrial or oil-prospecting zone, was chosen as the control. Ebocha, Idu Ekpeye and Obagi are oil prospecting/exploration areas. Agbada (Aluu), on the other hand, is an abandoned gas flaring site with a derelict borrow pit, while TransAmadi is the industrial base in Rivers state, Nigeria. 


\section{Collection of Samples}

Food crops used for the study were commonly consumed staples and vegetables. These were: Cassava (Manihot esculenta), a root crop and cocoyam corm (Colocasia esculenta); the vegetables were: pumpkin leaves (Telfairia occidentalis), waterleaf (Talinum trangulare) and okra (Hibiscus esculentus), a fruit vegetable. The crops were harvested at the peak of the harvest period between the months of May and July, from farms sited at oil prospecting or other industrial areas. The peak of the harvest period was chosen when farm crops were generally in their bloom, bearing in mind the fact that metal concentration in plants varies with the age of the plant as well as the season [2]. By arrangement with the respective farm owners, the various crops were randomly harvested from two or three farms within each location. Samples of each crop collected were wrapped in brown calico and transported to the laboratory for drying and analysis.

\section{Preparation of Samples}

Similar crop types collected from the different farms at each location were pooled. The green vegetables were removed from the stem before pooling, then washed in de-ionized water, drained in a colander and shredded prior to drying. The okra was similarly washed in de-ionized water and diced prior to drying. The root crops were also washed in water to remove soil and dirt, then peeled and sliced thinly before drying. All samples were dried in an air oven at $60^{\circ} \mathrm{C}$ for about 72 hours, then cooled to ambient temperature, milled by means of a hammer mill and sieved through a mesh of $1 \mathrm{~mm}$ diameter. The milled samples were stored in airtight plastic containers until required for analysis.

\section{Determination of metals}

Concentrated $\mathrm{HNO}_{3}(3 \mathrm{ml})$ and $0.5 \mathrm{ml} \mathrm{H}_{2} \mathrm{SO}_{4}$ were added to a $50 \mathrm{ml}$ flask containing $1 \mathrm{~g}$ ground oven-dried plant sample and $1 \mathrm{ml}$ of $60 \% \mathrm{HCLO}_{4}$ and $0.5 \mathrm{ml}$ concentrated $\mathrm{H}_{2} \mathrm{SO}_{4}$. The flask was swirled gently and the contents digested slowly on an electrothermal heater to $250^{\circ} \mathrm{C}$ for 15 minutes. The increase in temperature was gradual until it reached $250^{\circ}$. The digest was then cooled and filtered through 541 Whatman filter paper into a volumetric flask and diluted to $50 \mathrm{ml}$ with distilled water. The residual acid concentration of the digested sample was brought to $1 \% \mathrm{v} / \mathrm{v}$ after digestion. The digested samples were analysed for trace metals, using the Atomic Absorption Spectrophotometer, Model 451 [18]. The instrument was calibrated using standard solutions of lead, iron, copper and zinc. The absorbances obtained were used in calculating the concentrations of the metals in the different samples. 


\section{STATISTICAL ANALYSIS}

Statistical analysis of the data obtained was done using analysis of variance (ANOVA) according to the method of Wahua [19]. The least significant difference (LSD) was applied to show the means differences at $5 \%$ level of significance.

\section{RESULTS}

\section{Lead}

The results in Figures 1a, b and $\mathrm{c}$ show the mean concentrations of lead in various crops viz: cassava, cocoyam, okra, pumpkin leaves and waterleaf at various locations, namely: Agbada-Aluu (AA), Ebocha (EB), Idu Ekpeye (IE), Obrikom (OB), Trans-Amadi (TA) and the University Teaching and Research Farm (TF). In Figure 1a mean concentrations of lead in the various crops ranged from $1.1 \mu \mathrm{g} / \mathrm{g}$ in cocoyam from location TF to 9.1 $\mu \mathrm{g} / \mathrm{g}$ in okra in location TA. Details of the lead concentration are as follows: Cassava (root): from $1.2 \mu \mathrm{g} / \mathrm{g}$ in TF to $7.4 \mu \mathrm{g} / \mathrm{g}$ in OB; Cocoyam (corm): between $1.1 \mu \mathrm{g} / \mathrm{g}$ in TF and $2.6 \mu \mathrm{g} / \mathrm{g}$ in EB, Okra between $2.9 \mu \mathrm{g} / \mathrm{g}$ in EB and $9.1 \mu \mathrm{g} / \mathrm{g}$ in TA; for pumpkin leaves (Telfairia occidentalis), lead concentrations ranged from $2.4 \mu \mathrm{g} / \mathrm{g}$ and $2.6 \mu \mathrm{g} / \mathrm{g}$ in locations $\mathrm{AA}$ and $\mathrm{TF}$ respectively, to $8.6 \mu \mathrm{g} / \mathrm{g}$ in location TA. Waterleaf had lead concentrations between $2.0 \mu \mathrm{g} / \mathrm{g}$ in TF and $7.6 \mu \mathrm{g} / \mathrm{g}$ in EB.

Fig. 1: Mean concentrations of lead in crops at various locations

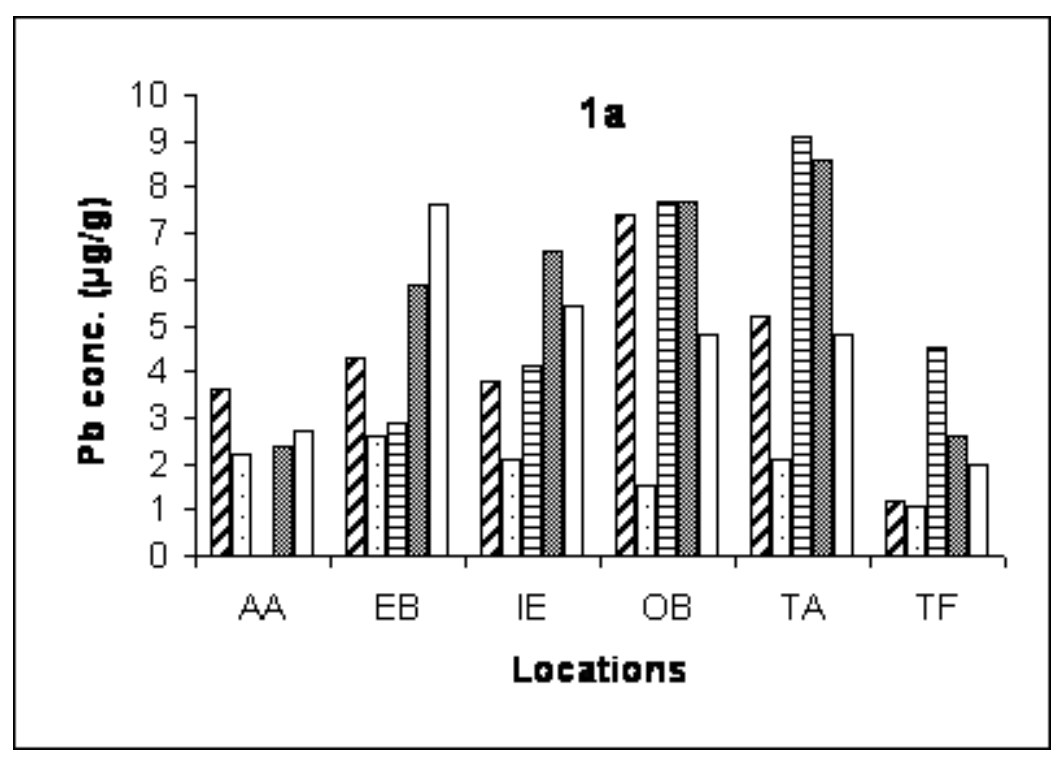



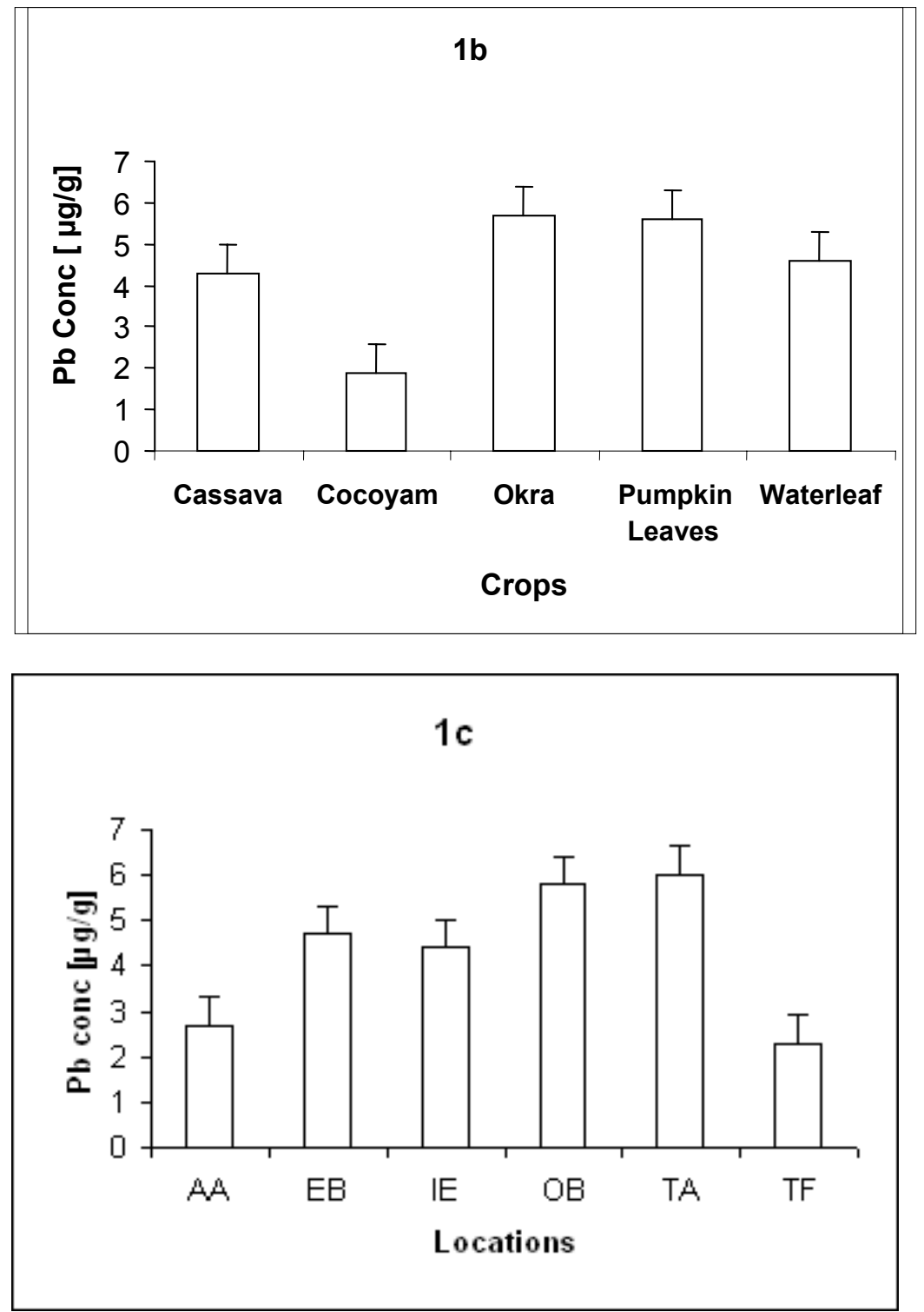
Hart AD Oboh CA Barimalaa IS and Sokari TG

Fig. 1: Legend

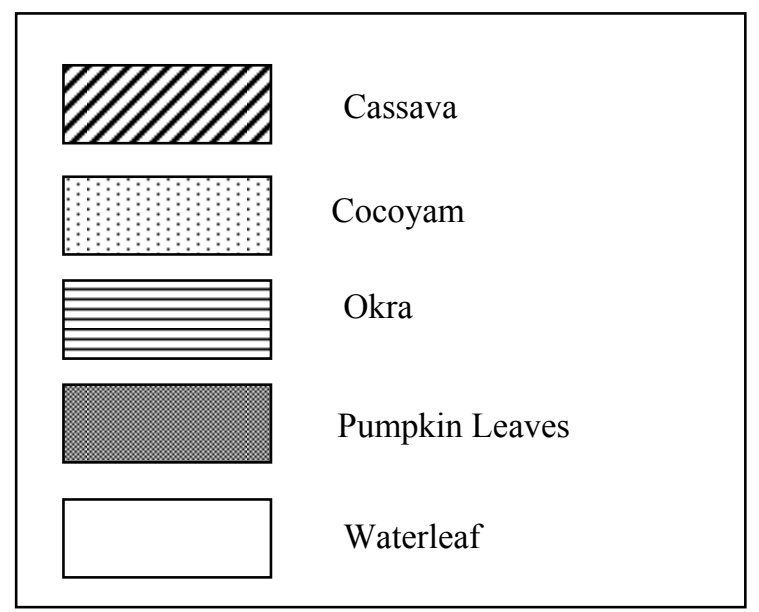

Figure $1 \mathrm{~b}$ shows that there was no significant differences in mean lead concentrations for okra, pumpkin leaves, waterleaf and cassava, while they differed significantly from cocoyam, which had the lowest lead concentration.

In Fig 1c, while TA, OB, IE and EB had significantly high concentration of lead and did not differ from one another, EB was the same as IE and AA but differed significantly from $\mathrm{TF}$.

\section{Iron}

Figures $2 \mathrm{a}, 2 \mathrm{~b}$ and $2 \mathrm{c}$ show iron concentrations in crops at various locations. In Figure 2a iron concentration ranged between $40 \mu \mathrm{g} / \mathrm{g}$ in cassava and $651 \mu \mathrm{g} / \mathrm{g}$ in pumpkin leaves thus: cassava: from $40 \mu \mathrm{g} / \mathrm{g}$ in TF to $93 \mu \mathrm{g} / \mathrm{g}$ in OB; cocoyam: from $44 \mu \mathrm{g} / \mathrm{g}$ in AA to $104 \mu \mathrm{g} / \mathrm{g}$ in TA; okra: $74 \mu \mathrm{g} / \mathrm{g}$ in TF to $277 \mu \mathrm{g} / \mathrm{g}$ in OB; pumpkin leaves: $162 \mu \mathrm{g} / \mathrm{g}$ in IE4 to $651 \mu \mathrm{g} / \mathrm{g}$ in TA, and waterleaf: $67 \mu \mathrm{g} / \mathrm{g}$ in TF to $275 \mu \mathrm{g} / \mathrm{g}$ in EB.

Pumpkin leaves had the highest mean concentration of iron, followed by waterleaf and okra, while iron concentration in okra did not differ significantly from that in cassava and cocoyam (Fig 2b).

Crops in locations TA and $\mathrm{OB}$ had the highest iron concentration, while crops from $\mathrm{OB}$, IE, EB, AA and TF did not differ significantly among themselves in iron content. (Fig 2c) 
Fig. 2: Mean concentrations of iron in crops at various locations
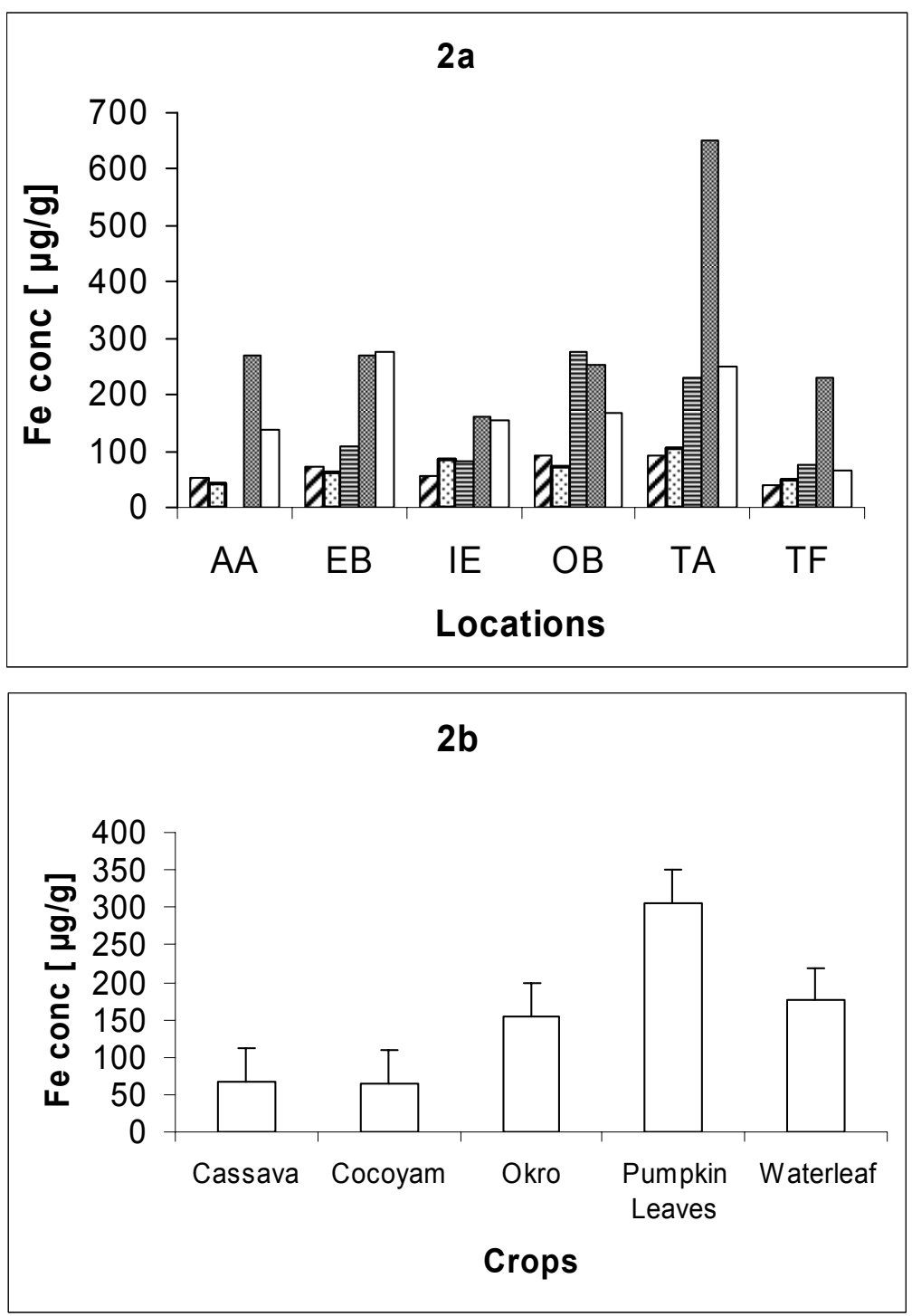


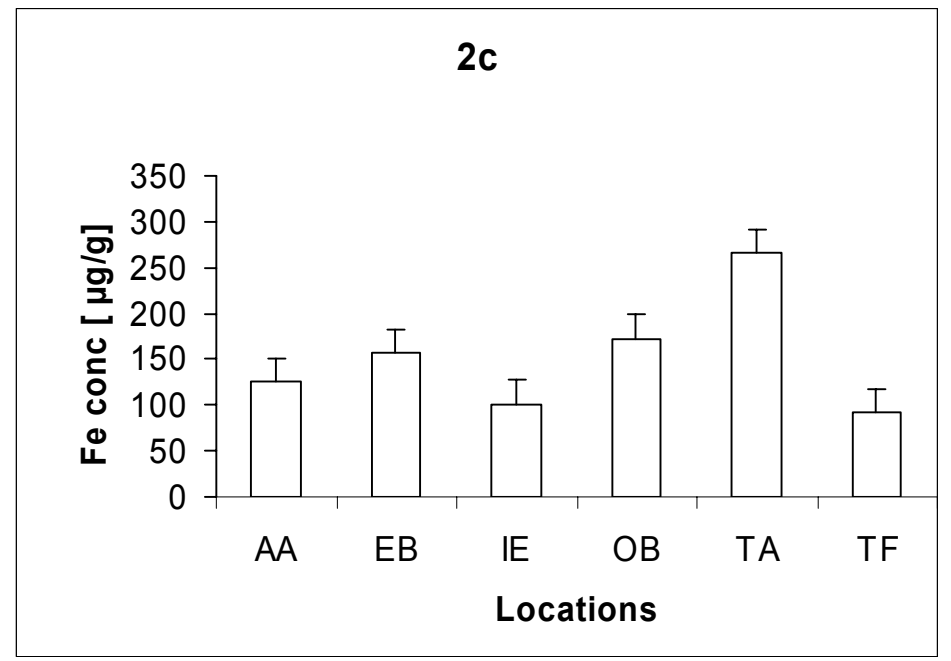

Hart AD Oboh CA Barimalaa IS and Sokari TG

Fig. 2: Legend

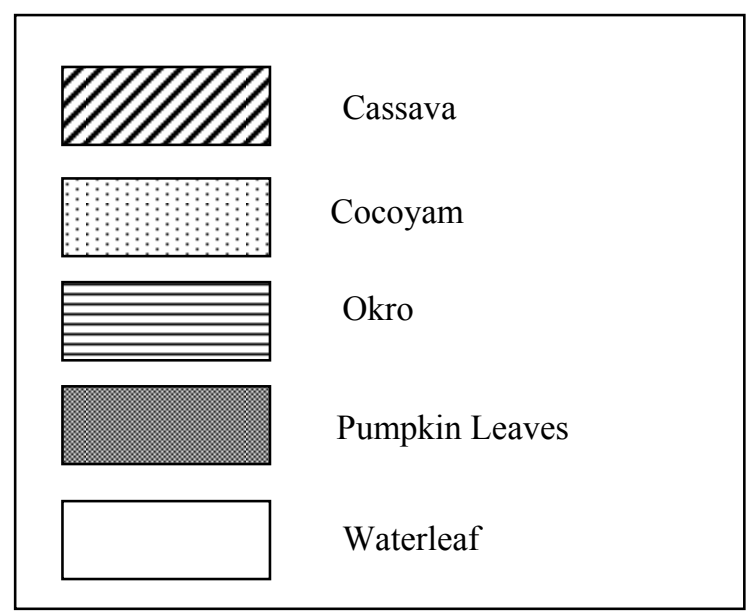

\section{Copper}

Figure 3a shows copper concentrations in crops at various locations, ranging from $4.4 \mu \mathrm{g} / \mathrm{g}$ in cocoyam from $\mathrm{TF}$ to $23 \mu \mathrm{g} / \mathrm{g}$ in pumpkin leaves from TA, distributed as 
Fig. 3: Mean concentrations of copper in crops at various locations
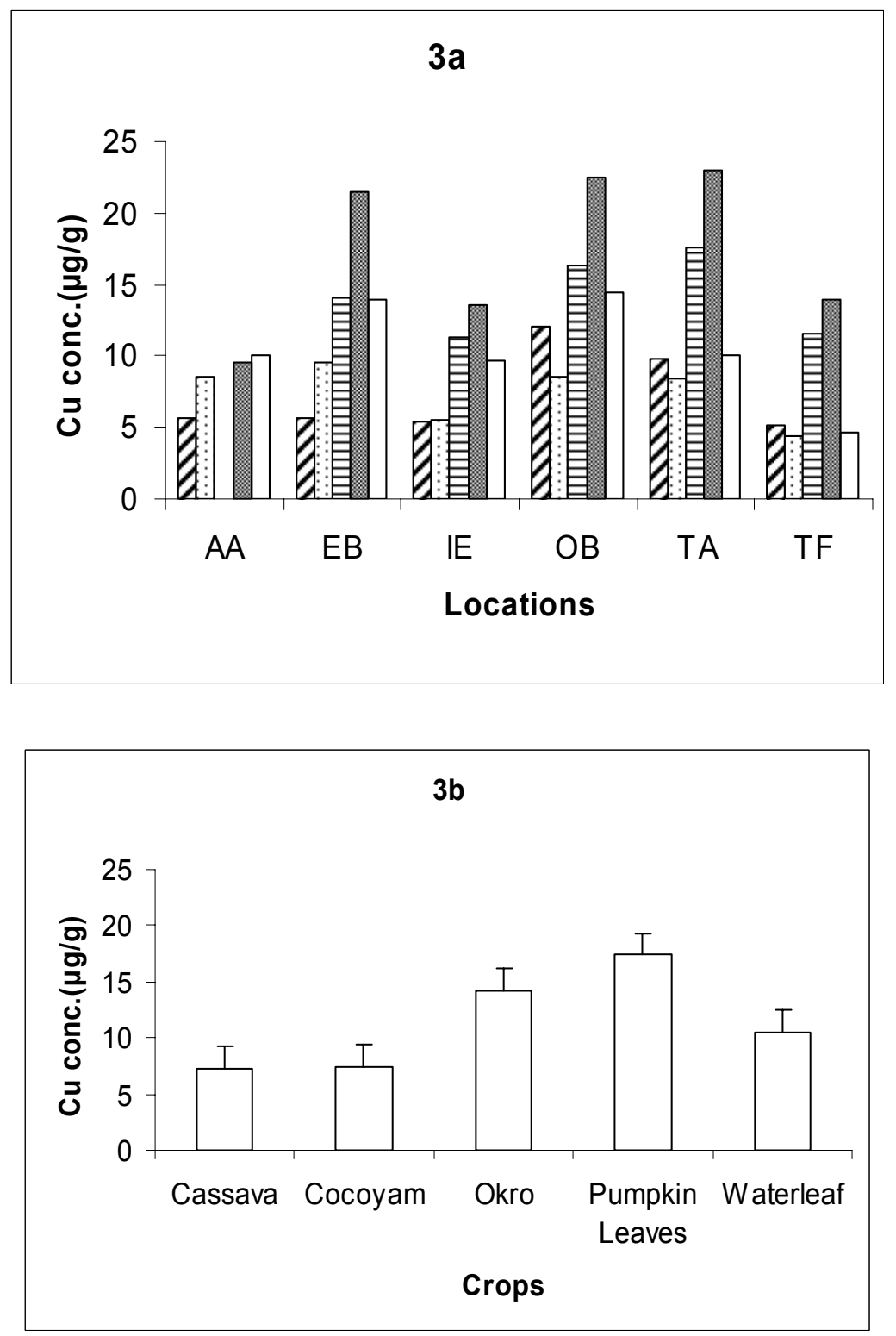


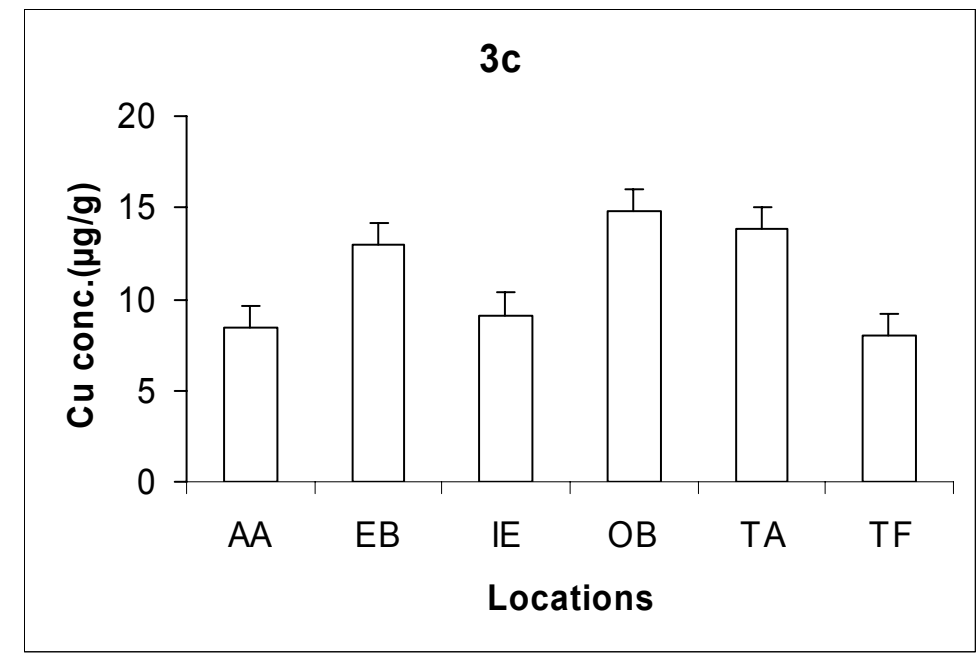

Hart AD Oboh CA Barimalaa IS and Sokari TG

Fig. 3: Legend

\begin{tabular}{|l|}
\hline Cassava \\
Cocoyam \\
\hline Okro \\
\hline Pumpkin Leaves \\
\hline \\
\hline
\end{tabular}


follows: Cassava - from $5.2 \mu \mathrm{g} / \mathrm{g}$ in TF to $12.1 \mu \mathrm{g} / \mathrm{g}$ in $\mathrm{OB}$; cocoyam $4.4 \mu \mathrm{g} / \mathrm{g}$ in TF to $9.5 \mu \mathrm{g} / \mathrm{g}$ in $\mathrm{EB}$; okra $-11.3 \mu \mathrm{g} / \mathrm{g}$ in IE to $17.6 \mu \mathrm{g} / \mathrm{g}$ in $\mathrm{TA}$; pumpkin leaves $-9.6 \mu \mathrm{g} / \mathrm{g}$ in AA to $23 \mu \mathrm{g} / \mathrm{g}$ in TA; waterleaf from $4.7 \mu \mathrm{g} / \mathrm{g}$ in TF to $14.5 \mu \mathrm{g} / \mathrm{g}$ in OB.

Figure $3 \mathrm{~b}$ shows that copper concentrations were significantly higher in pumpkin leaves than in okra, while okra had higher concentrations than waterleaf. Waterleaf, on the other hand, had higher concentration than cassava and cocoyam which did not differ significantly from each other.

In figure $3 \mathrm{c}$ showing concentrations of copper at various locations, crops from location TA, OB and EB had significantly higher concentrations than those from AA, IE and TF which did not differ from one another.

\section{Zinc}

In Figure 4a mean concentrations of zinc in crops ranged between $29 \mu \mathrm{g} / \mathrm{g}$ in cocoyam from $\mathrm{TF}$ to $240 \mu \mathrm{g} / \mathrm{g}$ pumpkin leaves from EB. In cassava, concentrations ranged from 84 $\mu \mathrm{g} / \mathrm{g}$ in TF to $154 \mu \mathrm{g} / \mathrm{g}$ in OB; in cocoyam, from $29 \mu \mathrm{g} / \mathrm{g}$ in AA and TF to $90 \mu \mathrm{g} / \mathrm{g}$ in EB; okra $-165 \mu \mathrm{g} / \mathrm{g}$ in TF to $240 \mu \mathrm{g} / \mathrm{g}$ in EB; pumpkin leaves $-136 \mu \mathrm{g} / \mathrm{g}$ in TF to $232 \mu \mathrm{g} / \mathrm{g}$ in $\mathrm{OB}$, and finally, in waterleaf, from $151 \mu \mathrm{g} / \mathrm{g}$ in TF to $216 \mu \mathrm{g} / \mathrm{g}$ in EB.

For mean concentrations of zinc, pumpkin leaves and okra had significantly higher concentrations than the rest of the crops, followed by waterleaf and then cassava, with the least concentration occurring in cocoyam (Fig. 4b).

In Figure4c, locations EB, OB and TA had crops with the highest concentrations of zinc. The concentration in locations IE and AA did not differ significantly from each other, while the 
Fig. 4: Mean concentrations of zinc in crops at various locations
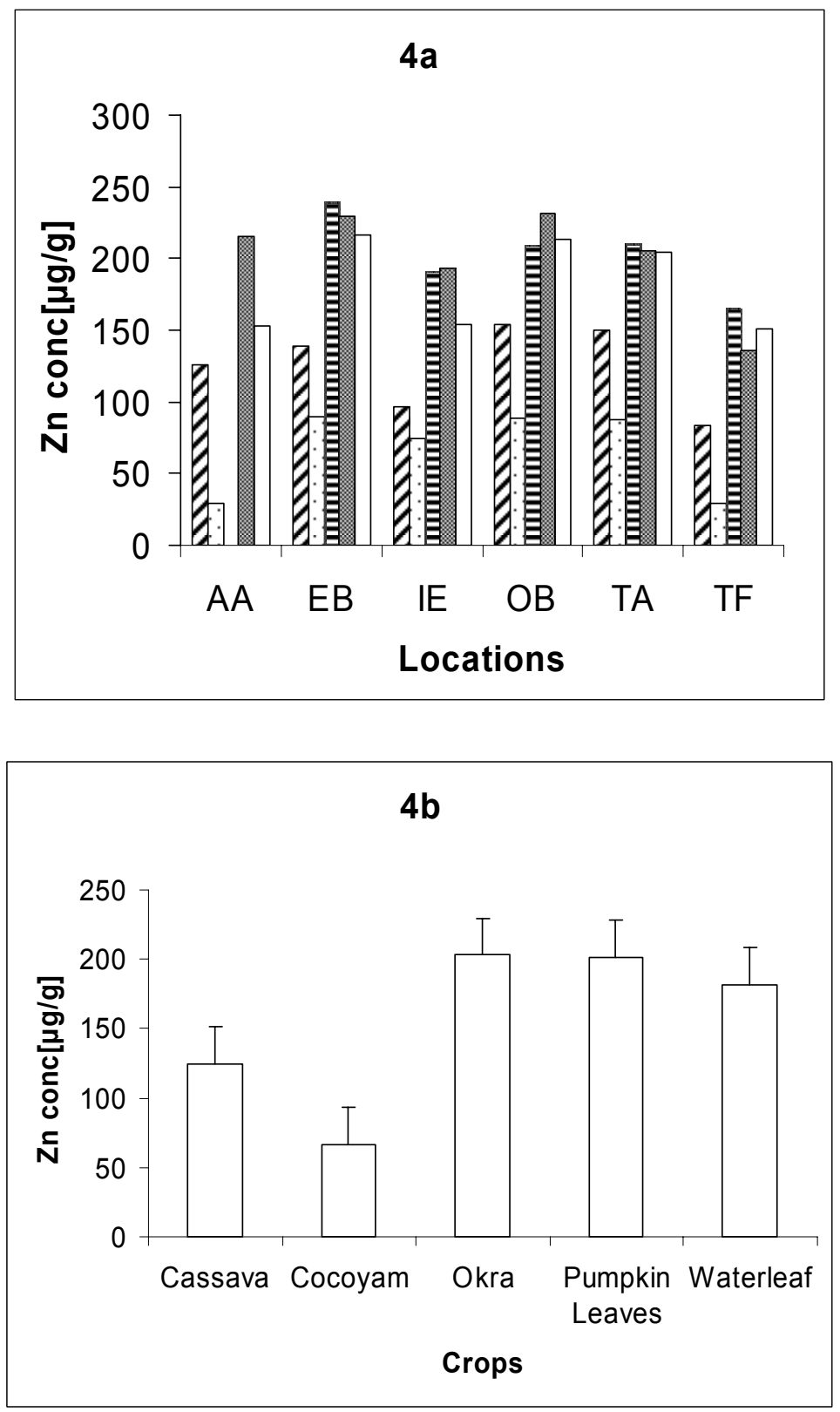


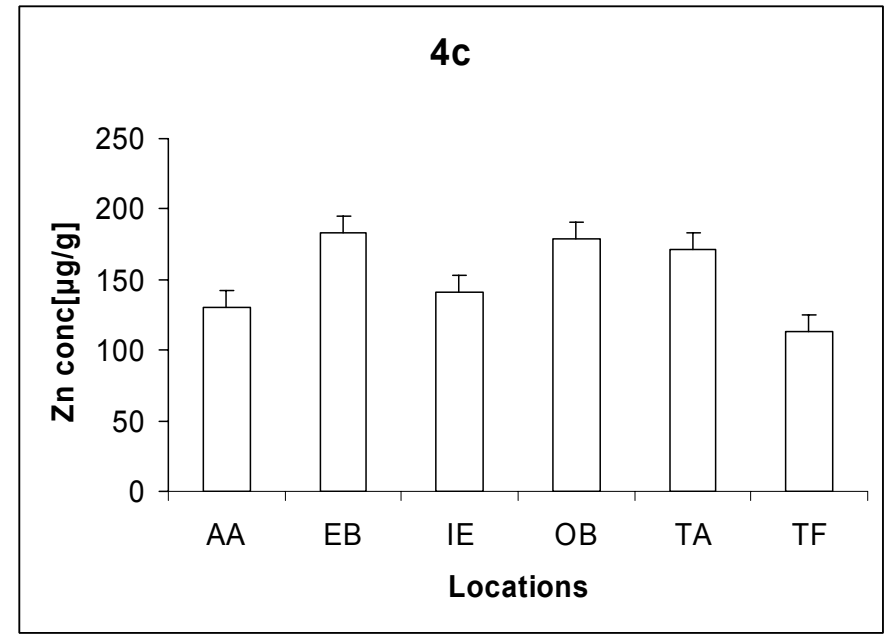

Hart AD Oboh CA Barimalaa IS and Sokari TG

Fig. 4: Legend

\begin{tabular}{|c|c|}
\hline \multirow[t]{2}{*}{ 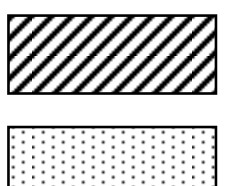 } & Cassava \\
\hline & Cocoyam \\
\hline \multirow{2}{*}{ 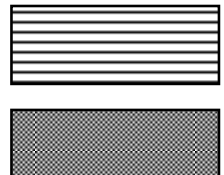 } & Okro \\
\hline & Pumpkin Leaves \\
\hline & Waterleaf \\
\hline
\end{tabular}


concentration in crops from location IE differed significantly from those procured from AA and TF, which had the lowest concentrations.

\section{DISCUSSION}

The significantly higher concentrations of lead occurring in crops from Trans Amadi (TA), Obrikom (OB), Idu Ekpeye (IE) and Ebocha (EB) \{Fig.1.\} strongly indicate the presence of heavy metal pollution (lead) from those highly industrialized areas. Previous work on heavy metals in seafoods commonly consumed in Rivers State in Nigeria had also shown lead concentrations of $6 \mathrm{mg}$ to $32 \mathrm{mg} / 100 \mathrm{~g}$ [20]. Another study done in Akwa Ibom State in Nigeria on pumpkin leaves grown in soil within the vicinity of a paint industry, had shown similar results as the present one, with lead concentrations of 0.034 and $0.086 \mathrm{mg} / 100 \mathrm{~g}$ [21].

With regard to the levels of lead in the various crops, the lowest concentration was found in cocoyam, while no significant differences occurred among the other crops, specifically, cassava, a root vegetable, okra, a fruit vegetable and then pumpkin leaves and waterleaf. These discrepancies could be because plants differ in their uptake of, and sensitivity to, lead - a factor which depends on certain soil conditions and root morphology [22,2]. However, it has been reported that in industrial societies, up to $0.2-$ $0.4 \mathrm{mg}$ lead may be ingested in the food daily, with $90 \%$ of this excreted in the faeces [23]. This situation notwithstanding, it is known that bioaccumulation of small doses of this metal over time can constitute a serious health hazard [5,24,25,2]. Thus the higher trends for lead obtained in crops from the highly industrialized locations could be potentially harmful since these common vegetables are frequently consumed in large quantities by the local people.

For iron, (Fig.2) the higher concentration in pumpkin leaves, followed by waterleaf and okra, all green vegetables, compared to cassava and cocoyam, might be due to the participation of the green vegetables in the synthesis of ferrodoxin, an attribute which makes them useful sources of iron. Pumpkin leaves, being of a darker green colour than waterleaf and okra, were significantly higher in iron content as noted by Davidson [23]. With respect to the locations, TA and $\mathrm{OB}$ which were among locations with the highest lead concentrations, also had the highest concentrations of iron in the crops, far beyond the normal levels of $1.0-4.0 \mathrm{mg} / 100 \mathrm{~g}$ reported in food composition tables [26].

Similar to iron, copper was found to occur in highest concentrations in pumpkin leaves, followed by the other green vegetables. (Fig.3). Cassava and cocoyam had the lowest concentrations of copper. With respect to location, the trend for copper followed the pattern for iron, being found in the highest concentrations in crops from the highly industrialized areas of TA, OB and EB. These findings all reinforce the presence of environmental pollution, particularly in the areas of increased industrial activities. The 
pollutants may have come not only from soil concentrations but also from aerial deposition as observed by Pilegaard and Johnsen [14].

As would be expected, crops from the non industrialised area, that is, the University Teaching and Research Farm (TF), in most cases, had the least concentrations of metals in the crops, providing further evidence of pollution from industrial activities in the other locations. In Agbada-Aluu (AA), the disused gas flare site, it is evident that the effect of the gas flares and other industrial activities may not have diminished and pollutants continue being retained in the soil. This deduction is based on the report that gas flares pollute the air and interfere with the growth and yield of most plants; in the case of okra, for instance, this is evidenced as failure to flower or fruit [27]. The unavailability of okra from farms in the Agbada-Aluu vicinity seems to support this view.

The uptake of metals by crops showed varying results: lead concentration was similar in all the crops except in cocoyam, where the concentration was significantly lower than in the other crops (Fig. 1b). On the contrary, the concentrations of iron and copper were significantly higher in pumpkin leaves than in all the other crops, while zinc concentration was highest in pumpkin leaves as well as okra $\{$ Fig. 4$\}$. These results are not consistent with literature reports which indicate that the highest concentrations of heavy metals occur in the lateral roots, then main roots, rhizomes, leaves, and the lowest in shoots [28]. On the other hand, Boon and Soltanpour reported in their study that leafy tissue concentrations of lead, cadmium and zinc sampled from garden vegetables grown in an old silver mine dump were highest. Root and other tuber crops were intermediate, lower than leaves, but higher than vegetable fruits [29].

Other studies showed varying results. However, in the case where lead concentration leafy vegetables were reportedly higher than the other parts of the plant, their metal uptake varied [29]. Members of the species Brassica oleracea did not accumulate lead in leaves, even when grown on highly contaminated soils, but accumulated cadmium and zinc, showing exception to the high lead concentrations in the leafy portion of the plant. Thus cabbage and broccoli leaves contained lead concentrations of less than $5 \mathrm{mg}$ per $\mathrm{kg}$, while lettuce and spinach contained from 41 to $45 \mathrm{mg}$ per $\mathrm{kg}$ of lead. Based on these findings which were corroborated by other studies cited in that report, recommendations were made to the Aspen and Boston Gardening Communities, that gardens with high lead levels (more than $1000 \mathrm{mg}$ per $\mathrm{kg}$ total lead) confine gardening to fruiting crops, which showed minimal lead uptake even in highly contaminated soils. Where soil lead was in the medium range (500-1000 mg per $\mathrm{kg}$ ), gardeners were advised to avoid leafy greens or develop container pots of clean soil for such crops. Consequently, harvesting of plant crops was discouraged in those gardens. The observed differences in uptake of metals may be due to crop type, as species differ in their mode of handling metals. This finding calls for further studies in the Niger Delta region with a preponderance of industries, to determine the heavy metal uptake characteristics of plants so as to minimize the risks of contamination of the food chain. 
While the essential elements, iron, copper and zinc are desirable in the nutrition of man, animals and plants, and their presence could reduce the bioavailability of lead, their undue presence in the food chain could be harmful $[23,30]$. Reports have indicated that excess amounts, as could result from industrial pollution, have varying deleterious effects on man. These range from severe mucosal irritation and corrosion, widespread capillary damage and central nervous system irritation, to possible necrotic changes in the liver and kidney in the case of copper [11]. With excessive intake of zinc and iron, vomiting, dehydration, electrolyte imbalance and lack of muscular co-ordination have also been indicated [11].

The observations in the present study call for continuous monitoring of the environment and the application of appropriate measures when there are danger signals. Such measures are necessary to preserve the health and safety of the people, not only in these highly industrialized areas, but the entire population as commodities so produced have a wider distribution than the immediate locality.

\section{CONCLUSION}

In conclusion, this study has revealed high concentrations of the heavy metal lead, with correspondingly high levels of iron, copper and zinc in various food crops harvested at areas of high industrial activities in Rivers State in Nigeria, compared to the non industrialized area. These findings are indicative of industrial pollution. Although the essential elements are beneficial to man and plants, when found in excessive amounts well above the levels normally found in food, can prove detrimental to health. This is more so when they exist in commonly consumed food crops, particularly the green vegetables which are generously consumed by all households especially during the season of abundance.

Although well regulated in some countries, industry has been the source of many contaminants and chemicals in food. Major industrial activities have the potential for generating air emissions, waste water effluence and solid wastes, all of which enter the food chain and cause danger to man, animals and plants. In view of these findings, there is need to monitor more closely the environment under review and put in place appropriate checks and balances to preserve the health of communities within the vicinity of the industrial areas, particularly as the effects of heavy metals are bioaccumulative and pose great dangers to the health of humans, animals and plants.

\section{ACKNOWLEDGEMENT}

Dr. Stanley Akele of Nigeria Agip Oil Company is gratefully

acknowledged for the use of laboratory facilities for chemical analysis. 


\section{REFERENCES}

1. Dambo WB Ecotoxicology of Heavy Metals and Petroleum Related Compounds on the Mangrove Oysters (Crasstrea rhizophorea) from the Lower Bonny Estuary. Ph.D Thesis 2000, Rivers State University of Science and Technology, Port Harcourt Nigeria.

2. Mogo FC Assessment of Heavy Metals in Soil, Water, Sediments and Certain Plant Taxa in Imo and New Calabar Rivers. Ph.D Thesis 2002, University of Port Harcourt, Port Harcourt, Nigeria.

3. Niger Delta Environmental Survey (NDES) Report Environmental and SocioEconomic Characteristics Phase 1 Report Vol.1. Submitted by the Environmental Resources Managers Ltd., Lagos, 1997.

\section{International Programme on Chemical Safety} http://www.who.int/pcs/training_material/hazardous_chemicals/section -1.htm.

5. Pickering KT and LA Owen Water Resources and Pollution. In: An Introduction to Global Environmental Issues $2^{\text {nd }}$ Ed London, New York 1997:187-207.

6. Carter DE and Q Fernando Chemical Toxicology.

J. Chem. Educ. 1979., 56: 8, 491-498.

7. Yeats PA and JM Brewers Potential Anthropogenic Influences on Trace Metal Distribution in the North Atlantic. Aquatic Science 1983; 40: 245-249.

8. Finn WA Disorder of Kidney and Urinary Tract In : AB Tarcher Ed. Principles and Practice of Environmental Medicine. Plenum Publishing Cooperation, NY and London 1992: $336-337$.

9. Laws A In: Aquatic pollution: An Introductory Text. Second Ed. An Interscience Publication 1993.

10. Burser AI and IP Efimov Chemistry Definitions, Notions and Technology. Mir Publishers, Moscow 1984.

11. WHO. Guideline for Drinking Water Quality. Health Criteria and Supporting Information 1984; 2, 63-315.

12. Csintalan $\mathbf{Z}$ and $\mathbf{Z}$ Tuba The Effect of Pollution on the Physiological Processes in Plants. In: M Kovacs Ed. Biological Indicators in Environmental Protection. NY 1992. 
13. Jones KC Contamination trends in soils and crops. Environmental Pollution 1991., 69:4, $311-326$.

14. Pilegaard K and I Johnsen Heavy Metal Uptake from Air and Soil by Transplanted Plants of Achilea millefolium and Hordeum vulgare.. L Ramussen Ed. Ecological Bulletin (NFR) (Ecotoxicology: $3^{\text {rd }}$ Oikos Conference) 1984., 36: 97-102.

15. Ndiokwere CC and CA Ezehe The Occurrence of Heavy Metals in the Vicinity of Industrial Complexes in Nigeria. Environment International. 1990., 16:291295.

16. Linden O Mission Report - Rivers State, Nigeria. Conclusion and Projects. Department of Zoology, Stockholm University, Sweden. October 1992.

17. World Bank Africa A Framework for Integrated Coastal Zone Management: Environmental Department, World Bank, Washington DC. 1995.

18. American Standard Testing On Spectrophotometer (AMST) 1982.

19. Wahua TAT Applied Statistics for Scientific Studies. Afrika-Link Press, Nigeria. 1999.

20. Hart AD Barimaala IS Oboh CA and F George Heavy Metal Concentrations in Some Seafoods Commonly Consumed in Selected Parts of Rivers State. Niger Delta Biologia 1998., 2:2, 44-47.

21. Udosen ED Levels of Toxic Metals in Telfairia occidentalis from a Paint Industry Environment. J. Appl. Chem. Agric. Res. 1994., 1:1, 35-42.

22. Hemphill DD Availability of Trace Elements to Plants with Respect to Soil-Plant Interaction. Ann. NY. Acad.Sci. 1972., 199: 46-61.

23. Davidson S Passmore R Brock JF and AS Truswell Trace Elements In: Human Nutrition and Dietetics Churchill Livingstone $7^{\text {th }}$ Ed. 1979., 107-116.

24. Woodwell GM Toxic Substances and Ecological Cycles. In; JE Hoff and J Jaruck. Readings from Scientific American: FOOD. WH Freeman and Co., San Francisco. 1973., 72-79.

25. More MR Diet and Lead Toxicity. Proc. Nutr. Soc. 1979., 38: 243-250. 
26. Platt BS Tables of Representative Values of Foods Commonly Used in Tropical Countries. Medical Research Council. Special Report Series No 302 (Revised Edition of SRS 253) London: Her Majesty's Stationery Office. 1980.

27. Imevbore AMA and SA Adeyemi Environmental Monitoring in Relation to Prevention and Control of Oil pollution. The Petroleum Industry and the Nigerian Environment. Proceedings of an International Seminar Sponsored by the Nigerian National Petreoleum Corporation (NNPC). Published by Thomopulos Environmental Pollution Consultants in Cooperation with NNPC Nov 9-12 1981., 135-142.

28. Romera $\mathbf{F}$ Benloch $M$ Lora A Alcantara $\mathbf{E}$ and $\mathbf{E}$ Sancho Preliminary Evaluation of Phytoremediation Techniques Applied to a Metal Contaminated Area. Working Group 4. Cultivation of Utilization of Plants. Abstracts Presented in Lisbon. http://lbewww.epfl.ch/cost837/WG4/ablisbon. html.

29. Boon DY and PN Soltanpour Lead, Cadmium and Zinc Contamination of Aspen Garden Soils and Vegetation. J. Envir. Qual. 1992; 21:1, 82-86

30. Udosen ED Udoessien EI and UJ Ibok Evaluation of some Metals in the Industrial Wastes from a Paint Industry and their Environmental Pollution Implications. Nig J. Tech. Res. 1990., 2: 71-77. 